\title{
Simultaneous Determination of Transition Metals in Hazelnuts (Corylus avellana L.) by ICP-OES
}

\author{
K. Serdar Celik ${ }^{a}$, Firat Aydin's*, M. Zahir Duz ${ }^{\mathbf{b}}$, Isil Aydin', Sait Erdogan', \\ Osman Akba ${ }^{\text {, }}$, and Candan Hamamci ${ }^{\mathbf{b}}$ \\ a Batman University, Science and Art Faculty, Chemistry Department, Batman, Turkey \\ b Dicle University, Science Faculty, Chemistry Department, Diyarbakir, Turkey \\ c Dicle University, Pharmacy Faculty, Analytical Chemistry Department, Diyarbakir, Turkey
}

\section{INTRODUCTION}

Establishing the inorganic profile of foods is important because of the metabolic role of some elements in the human organism. On the other hand, how to verify that the food does not contain minerals in quantities toxic to the health of the consumer is of great concern, regardless whether this presence of minerals is naturally occurring or is due to contamination during the production processes (1). Nuts are referred to as dried fruits in seeds, fruit with split hulls, or the edible seed kernel of trees (2). They were one of the first foods available to man, yet they have received relatively little attention in a modern mixed diet or in nutritional studies published during the last three decades (3). Currently, over $4,000,000$ t of nuts are commercially produced worldwide of which $700,000 \mathrm{t}$ is hazelnut production. The mineral composition of nuts is influenced by factors such as climate, soil characteristics (content of organic matter, $\mathrm{pH}$, and clay mineralogy), variety, transport, storage, and preparation. These factors vary from one region to another and even within the same country (4). Several recent reports have focused on the determination of the essential and trace elements in nuts and seeds (i.e., B, Se, Cu, $\mathrm{Zn}, \mathrm{Fe}$, and Mn) (5-9). This may be due to the increasing recognition of nuts and seeds as important sources of some essential elements

\footnotetext{
*Corresponding autbor.

:E-mail: firataydin01@gmail.com

Tel: +904122488550 (Ext.3057)

Fax: +904122488300
}

\section{ABSTRACT}

Heavy metal concentrations in foods are of interest because of their essential or toxic nature. The present work reports the results obtained for the simultaneous determination of essential and/or toxic metals (Cd, Co, Cr, $\mathrm{Cu}, \mathrm{Fe}, \mathrm{Ni}, \mathrm{Pb}, \mathrm{Zn}$ ) in 24 hazelnut samples by inductively coupled plasma optical emission spectrometry (ICP-OES) after sample digestion using a diluted oxidant mixture in a closed-vessel microwave system. The obtained results (mean in $\mathrm{mg} / \mathrm{kg}$ ) were: Co 1.15, Cr 1.92, Cu 17.96 $\mathrm{Fe} 489$, Ni 4.76, and $\mathrm{Zn} 85$. The concentrations of $\mathrm{Cd}$ and $\mathrm{Pb}$ were below the detection limits and are below the daily intake recommended by the international organizations (WHO). Therefore, it can be stated that hazelnuts are safe for public consumption. The macro and micro nutrient ranges in hazelnut (Corylus avellana L.) did not exceed the dietary reference intake (DRI).
\end{abstract}

in human nutrition, as well as the growing popularity of various health diets that rely on the frequent use of these constituents. On the other hand, the reported accumulation of toxic elements $(\mathrm{Pb}, \mathrm{Cd})$ in these matrices in some cases may compromise the use of nuts and seeds in human nutrition $(3,10-12)$.

Studies on the metal content in foods are gaining more and more importance because of their nutritional value and their possible toxicological effects. The major source of these elements for the body is from food (13-15). For example, iron, zinc, copper, chromium, and cobalt are essential, while lead, cadmium, and nickel are toxic at certain levels (16). Thus, validated methods to measure the essential mineral composition of food matrices are needed to satisfy the analytical requirements of product development, quality control, and the food regulatory authorities (17). Dietary intake of 'essential minerals' is necessary to support normal growth, reproduction, and health during the human life cycle and can occur only when the nutritional requirements are held at optimal levels (18).

Optical emission spectrometry (OES), also known as atomic emission spectrometry (AES), allows sensitive multielemental analysis because characteristic emission spectra can be generated for a range of elements under the same excitation conditions. Since all atoms in a sample are excited simultaneously, they can be detected simultaneously, which is the major advantage of OES. Inductively coupled plasma optical emission spectrometry (ICP-OES) provides a higher reproducbility and quantitative linear range. Argon is usually used as the atomizer because it produces a chemically inert environment, generates very high temperatures that ensure almost complete atomization, and provides a calibration range of several orders of magnitude (18-23).

All spectrometric techniques for elemental analysis are subject to spectral interferences. The optimal method for a given sample is often a compromise between minimizing 
the respective interferences affecting the analytes and achieving acceptable detection limits in view of the sample matrix and the expected elemental composition. In addition, there may be pragmatic concerns to minimize the analytical run time and expense (17).

Environmental pollution is the main cause of contamination from toxic elements in the food chain. Since $\mathrm{Pb}$ and $\mathrm{Cd}$ are potentially harmful metals, there is considerable concern (World Health Organization 2011) (10). In comparion to ICP-OES or atomic absorption spectrometry (AAS) analysis, inductively coupled plasma mass spectrometry (ICP-MS) results in better detection limits (ppt-ppb level), similar or better precision (19), and is becoming the more commonly used analytical tool in food laboratories.

\section{Essential Elements}

Metals such as $\mathrm{Cu}, \mathrm{Fe}$, and $\mathrm{Zn}$ are essential for humans. For example, $\mathrm{Cu}$ is important in respiration for the synthesis of hemoglobin, the protein that transports oxygen into the blood stream. Moreover, it participates in the synthesis of collagen and the neurotransmitter noradrenalin, which is one of the most important blood antioxidants and helps to prevent breakdown of polyunsaturated fatty acids to keep the cell membrane healthy. Iron is also necessary for the synthesis of collagen and is present in the brain as a co-factor in the synthesis of serotonin, dopamine, and noradrenalin neurotransmitters. Its principal function is through its interaction with proteins and copper in the formation of hemoglobin. Zinc is the most ubiquitous of all trace elements involved in the human metabolism. More than 100 specific enzymes require zinc for their catalytic function (20). Essential trace elements such as $\mathrm{Cu}$ and $\mathrm{Zn}$ play an important role in human biology, because they are inadequately or not at all synthesized in the body.

\section{Toxic Elements}

On the other hand, toxic elements such as $\mathrm{Pb}$ and $\mathrm{Cd}$ are not required for the normal functioning of living processes and no beneficial health effects are known. Heavy metals are associated with a myriad of adverse health effects, including allergic reactions (i.e, $\mathrm{Cr}$ and $\mathrm{Ni}$ ), neurotoxicity (i.e, $\mathrm{Pb}$ ), anemia and stomach and intestinal irritation (e.g., $\mathrm{Cu}$ ). On the other hand, metals such as $\mathrm{Pb}, \mathrm{Cd}, \mathrm{Cr}, \mathrm{Ni}$, $\mathrm{Cu}, \mathrm{Al}, \mathrm{Fe}$, and $\mathrm{Zn}$ are known to become potentially toxic when present at high concentrations. By monitoring the range of heavy metals we may be able to perform mitigation measures for the metal of interest whose concentration is higher than the permissible limits (21).

\section{Hazelnuts (Corylus sp. L.)}

The hazel plant is a perennial shrub, has oval, tooth-edged leaves and clusters of small flowers which produce light brown, oval or round, edible nuts. The hazelnut (Corylus sp. L.), a member of the birch family, Betulaceae, is an important commercial and subsistence crop in many countries including Turkey, Spain, Italy, and the USA (24). Turkey is the world's leading country in hazelnut production and export. Turkey has 28-30 million hazel shrubs and produces about 550,000 t of hazelnuts annually, which is approximately $80 \%$ of the world's hazelnut production. Other countries producing hazelnuts are Italy with $110,000 \mathrm{t}$, the USA with 25,000 t, and Spain with $18,000 \mathrm{t}$ per year (2). In addition, Turkey is the largest exporter of hazelnuts, which accounts for $12 \%$ of its foreign trade earnings. Thus, the hazelnut is a very important horticultural product for Turkey's economy. High-quality hazelnuts are cultivated mainly in the Black Sea region due to the suitable climate conditions. The development of a precise and easy method for

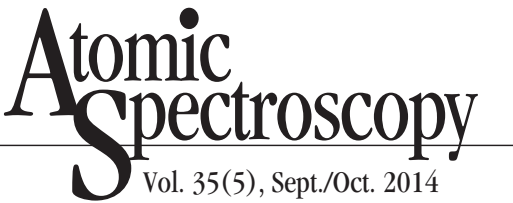

the determination of metals in nuts is essential since the hazelnut plays a major role in human nutrition due to its very special content of proteins, carbohydrates, fats, vitamins, and minerals.

The hazelnut provides high energy (27.17-28.46 MJ/kg), containing $61.66 \%$ oil, $20.59 \%$ protein, and $10 \%$ carbohydrates as the mean values. Its oil is unique in that only two fatty [oleic (C 18:1, $80 \%$ ) and linoleic (C18:2, 12\%)] acids account for $90 \%$ of the fatty acid content. The moisture and ash content of the hazelnut varieties ranges from $2.49 \%$ to $5.25 \%$ and between $1 \%$ and $3.4 \%$, respectively (24-26).

\section{Method of Analysis}

Based on the importance of the hazelnut as a mineral source for human consumption and the need to understand its mineral composition, a simple, robust, and reliable analytical method for the simultaneous determination of macro and micro elements in hazelnuts by ICP-OES is presented. The effectiveness of a closed-vessel microwave oven method in combination with a diluted oxidant mixture $\left(\mathrm{HNO}_{3} / \mathrm{H}_{2} \mathrm{O}_{2} / \mathrm{H}_{2} \mathrm{O}\right)$ to digest the high organic content of the samples analyzed in this work is demonstrated.

\section{EXPERIMENTAL}

\section{Instrumentation}

An Optima ${ }^{\mathrm{TM}} 2100$ DV (dual view) inductively coupled plasma optical emission spectrometer (PerkinElmer, Inc., Shelton, CT, USA) was used for the determination of $\mathrm{Cd}, \mathrm{Co}, \mathrm{Cr}, \mathrm{Cu}, \mathrm{Fe}, \mathrm{Ni}, \mathrm{Pb}$, and $\mathrm{Zn}$ in the hazelnut samples in diluted solutions. The ICP-OES operating conditions are listed in Table I. All of the procedures from sampling to analysis were also applied to blanks in order to evaluate any metal contamination during the analytical procedure. A blank was simultaneously prepared and 
all procedures were applied before measurements. Selection of the instrumental parameters and the optical wavelengths was based on obtaining good sensitivity, reasonable detection limits, and eliminating interferences. All samples were digested and analyzed in triplicate.

The reagents used $\left(\mathrm{HNO}_{3}, 65 \%\right.$, and $\mathrm{H}_{2} \mathrm{O}_{2}, 30 \%$ ) were of analytical grade (E. Merck, Darmstadt, Germany) and used without further purification. Deionized distilled water was used throughout and directly obtained from a Milli- ${ }^{\circledR}$ system (Millipore Corporation, USA). Adjustment of the instrumental parameters was essential for the simultaneous determination of the eight elements studied covering a spectral wavelength range of $206.200 \mathrm{~nm}$ to $327.393 \mathrm{~nm}$.

\section{Sample Preparation}

For this study, 24 hazelnut samples were obtained from the markets in Diyarbakir, Turkey, in 2012. In order to preserve the original quality of the hazelnuts, the samples were stored at ambient temperature in sealed plastic bags prior to any conditioning.

\section{Certified Reference Material}

Certified standard reference material (CRM) NIST 1573a Tomato Leaves (National Institute of Standards and Technology, Gaithersburg, MD, USA) was used to assess the accuracy and precision of the method. As can be seen in Table II, the proposed method was validated through the analysis of this CRM with good accuracy and recoveries.

\section{Microwave Digestion}

A Berghof MWS-3 model microwave digestion system (Berghof, USA) was used for digestion of the hazelnut samples. A portion of $0.2 \mathrm{~g}$ dried sample and standard reference material was weighed and transferred into pressure-resistant PTFE vessels,
TABLE I

Instrumental Operating Conditions Using the Optima ${ }^{\mathrm{TM}} 2100$ DV ICP-OES

\begin{tabular}{ll}
\hline Parameters & \\
\hline RF power & $1450 \mathrm{~W}$ \\
Plasma gas flow rate & $15 \mathrm{~L} \mathrm{~min}^{-1}$ \\
Auxiliary gas flow rate & $0.2 \mathrm{~L} \mathrm{~min}^{-1}$ \\
Nebulizer gas flow rate & $0.8 \mathrm{~L} \mathrm{~min}^{-1}$ \\
Sample flow rate & $1.5 \mathrm{~mL} \mathrm{~min}^{-1}$ \\
View mode & Axial \\
Read & Peak area \\
Source equilibration time & $15 \mathrm{~s}$ \\
Read delay & $50 \mathrm{~s}$ \\
Replicates & 3 \\
Background correction & 2 -point (manual point correction) \\
Spray chamber & Scott type spray chamber \\
Nebulizer & Cross-flow GemTip ${ }^{\mathrm{TM}}$ nebulizer \\
& (HF resistant) \\
Detector & Solid state detector (CCD) \\
Purge gas & Nitrogen \\
Shear gas & Air \\
Plasma gas & Argon \\
Anaytical wavelengths & Cd 228.802 nm, Co 228.616 nm. \\
& Cr 267.716 nm, Cu 327.393 nm, \\
& Pe 238.204 nm, Ni 231.604 nm, \\
& \\
&
\end{tabular}

TABLE II

Accuracy Assessment of Analysis of CRM NIST 1573a Tomato Leaves

\begin{tabular}{cccc}
\hline Element & Mass No. & Certifed $(\mathrm{mg} / \mathrm{kg})$ & Found $(\mathrm{mg} / \mathrm{kg})$ \\
\hline $\mathrm{Cd}$ & 114 & $1.52 \pm 0.04$ & $1.58 \pm 0.08$ \\
$\mathrm{Co}$ & 59 & $0.57 \pm 0.02$ & $0.52 \pm 0.01$ \\
$\mathrm{Cr}$ & 53 & $1.99 \pm 0.06$ & $2.05 \pm 0.12$ \\
$\mathrm{Cu}$ & 63 & $4.70 \pm 0.14$ & $4.77 \pm 0.05$ \\
$\mathrm{Fe}$ & 56 & $368 \pm 7$ & $372 \pm 5$ \\
$\mathrm{Ni}$ & 60 & $1.59 \pm 0.07$ & $1.63 \pm 0.06$ \\
$\mathrm{Zn}$ & 65 & $30.9 \pm 0.7$ & $31.8 \pm 1.3$ \\
\hline
\end{tabular}


then $4 \mathrm{~mL}$ of a diluted oxidant mixture $\left(\mathrm{HNO}_{3} / \mathrm{H}_{2} \mathrm{O}_{2} / \mathrm{H}_{2} \mathrm{O}, 2: 1: 1\right)$ was added to each sample. The vessels were closed and a total of six samples were evenly spaced on the microwave oven carousel. The temperature program of the microwave acid digestion (MW-AD) is listed in Table III. The power applied was $700 \mathrm{~W}$.

After the digestion procedure, the reaction mixture was evaporated in order to remove the acids. Then the residue was diluated to $100 \mathrm{~mL}$ with deionized distilled Milli- $\mathrm{Q}^{\mathrm{TM}}$ water as final volume. The ICP-OES measurements of $\mathrm{Cd}, \mathrm{Co}, \mathrm{Cr}, \mathrm{Cu}$, $\mathrm{Fe}, \mathrm{Ni}, \mathrm{Pb}$, and $\mathrm{Zn}$ were performed for the diluted solutions (27-33).

\section{Analytical Procedure}

The limits of detection (LOD) and limits of quantification (LOQ) for each metal were determined as follows: 10 independent analyses of a blank solution spiked with the metal at a level of lower concentration of the analytical curve were performed. The LOD and LOQ were calculated from the standard deviation $(\sigma)$ of these determinations $(\mathrm{LOD}=3 \times \sigma$ and $\mathrm{LOQ}=$ $10 \times \sigma)$. The analytical wavelengths, average detection limits calculated for all measurements, and the average concentration of the elements in the hazelnut samples are listed in Table IV.

\section{RESULTS AND DISSCUSSION}

A method for the simultaneous determination of $\mathrm{Cd}, \mathrm{Co}, \mathrm{Cr}, \mathrm{Cu}$, $\mathrm{Fe}, \mathrm{Ni}, \mathrm{Pb}$, and $\mathrm{Zn}$ in hazelnuts using inductively coupled plasma optical emission spectrometry is presented. One hundred grams of hazelnuts provides energy of 600-650 kcal. The ash content in hazelnuts varies from 1 to $3.4 \%$ (26). To determine the trace element content by atomic spectrometry techniques requires digestion and conversion of the solid food samples into solution form prior to measurement. Many procedures have been developed to shorten the analysis time and to minimize the problems associated with solid sample pretreatment such as sample contamination and analyte loss (13,34-36). For example, the microwave digestion of solid samples followed by an ICP-OES or ICPMS analysis is a powerful approach to the complete decomposition and accurate determination of metals in food samples (36). In this study, a diluted oxidant mixture $\left(\mathrm{HNO}_{3} /\right.$ $\left.\mathrm{H}_{2} \mathrm{O}_{2} / \mathrm{H}_{2} \mathrm{O}, 2: 1: 1\right)$ was used to achieve the complete decomposition of the organic matrix in a closed-vessel microwave oven. Table IV shows that the metals of highest concentration in hazelnuts are $\mathrm{Fe}, \mathrm{Zn}$, and $\mathrm{Cu}$ (Fe, $489 \mathrm{mg} / \mathrm{kg}$; $\mathrm{Zn}, 85 \mathrm{mg} / \mathrm{kg}$, and $\mathrm{Cu}, 17.96$ $\mathrm{mg} / \mathrm{kg}$ ), while Co is present at the lowest concentration $(1.15 \mathrm{mg} / \mathrm{kg})$, and $\mathrm{Pb}$ and $\mathrm{Cd}$ is not detected at all.

TABLE III

Temperature Program of the Microwave Digestion System for Hazelnut (Corylus avellana L.) Samples

\begin{tabular}{lrrrr}
\hline Step & 1 & 2 & 3 & 4 \\
\hline $\mathrm{T}\left({ }^{\circ} \mathrm{C}\right)$ & 120 & 170 & 180 & 100 \\
$\mathrm{~T}(\mathrm{~min})^{\mathrm{a}}$ & 5 & 4 & 4 & 5 \\
Time $(\min )^{\mathrm{b}}$ & 5 & 4 & 4 & 6 \\
\hline
\end{tabular}

a Waiting time at desired temperature.

b Time between the two sequential temperatures.

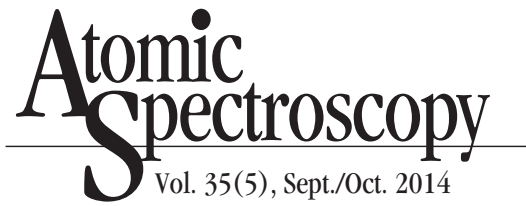

The results presented in this paper enlarge the knowledge of the elemental composition of hazelnuts and will be useful and of interest in the toxicological and nutritional fields (36). The results of this study show that the concentrations of heavy metals are below the daily intake as recommended by the international organizations (19,3740). The Food and Agriculture Organization/World Health Organization (FAO/WHO) has defined the provisional tolerable weekly intake (PTWI) (40) for a chemical with no intended function as an estimate of the amount of the chemical that can be ingested weekly over a lifetime without appreciable health risk $(11,32)$. The hazelnut samples used in this research were found not to be polluted with toxic metals since the concentrations of the heavy metals were all below the WHO (40) permissible limits and the USP2232 Elemental Contaminants in Dietary Supplements publication (19). Therefore, it can be stated that hazelnuts are safe for public consumption.

Table IV

Average Detection Limits and Average Concentration of Elements in Hazelnut Samples

\begin{tabular}{lcc}
\hline $\begin{array}{c}\text { Ele- } \\
\text { ment }\end{array}$ & $\begin{array}{c}\text { LOD } \\
(\mu \mathrm{g} / \mathrm{kg})\end{array}$ & $\begin{array}{c}\text { Concentration } \\
(\mathrm{mg} / \mathrm{kg})\end{array}$ \\
\hline $\mathrm{Cd}$ & 22.0 & N.D. \\
$\mathrm{Co}$ & 15.0 & $1.15 \pm 0.08$ \\
$\mathrm{Cr}$ & 23.0 & $1.92 \pm 0.24$ \\
$\mathrm{Cu}$ & 5.5 & $17.96 \pm 1.56$ \\
$\mathrm{Fe}$ & 7.1 & $489 \pm 8$ \\
$\mathrm{Ni}$ & 30.0 & $4.76 \pm 0.28$ \\
$\mathrm{~Pb}$ & 25.0 & $\mathrm{~N} . \mathrm{D}$. \\
$\mathrm{Zn}$ & 10.0 & $85 \pm 2$ \\
\hline
\end{tabular}




\section{CONCLUSION}

Turkey has agricultural growing conditions that are suitable for cultivating a variety of high quality hazelnuts. The proposed ICP-OES technique developed and validated for hazelnut (Corylus avellana L.) samples proved to be simple, rapid, accurate, and precise for the simultaneous determination of eight essential and nonessential/toxic elements (Cd, Co, Cr, Cu, Fe, Ni, Pb, and $\mathrm{Zn}$ ). The method can also be considered useful for the routine determination of trace elements in foods and similar matrices, as well as for quality control purposes. The accuracy of the method was verified and compared well with the certified values.

This study shows that the heavy metal concentrations $(\mathrm{Cd}, \mathrm{Pb}$, and $\mathrm{Zn}$ ) of the hazelnuts (Corylus avellana $L$.) grown and harvested in Turkey were found to be below the WHO permissible limits and, therefore, are safe for public consumption.

Received March 9, 2014.

\section{REFERENCES}

1. I. J. Cindric, M. Zeiner and I. Steffan, Microchem. J. 85, 136 (2007).

2. F. Ozdemir and I. Akinci, J. Food Eng. 63, 341 (2004).

3. I. Rodushkin, E. Engström, D. Sörlin and D. Baxter, Sci. Total Environ. 392, 290 (2008).

4. S. Pereira-Lorenzo, A.M. RamosCabrer, M.B. Diaz-Hernandez, M. Ciordia-Ara, and D. Rioz-Mesa, Sci. Hortic. 107, 306 (2006).

5.M. Plessi, D. Bertelli, A. Monzani, M. S. Simonetti, A. Neri, and P. Damiani, J. Food Comp. Anal. 12,91 (1999).

6. C. Cabrera, F, Lloris, R. Gimenez, M. Olalla and C. Lopez, Sci. Tot. Environ. 308, 1 (2002).
7. C. Hamamci, B. Gumgum, O. Akba, and S. Erdogan, Fresenius Environ. Bull. 6, 430 (1997).

8 J. De La Montana Miguelez, M. Miguez Bernardez, and J.M.Queijeiro, Food Chem. 84, 401 (2004).

9. A.A. Momen, G.A. Zachariadis, A.N. Anthemidis, and J.A. Stratis, Talanta 71, 443 (2007).

10. A. L. H. Muller, C. C. Muller, F. Lyra, P. A. Mello, M. F. Mesko, E. I. Muller and E. M. M. Flores, Food Anal. Methods 6, 258 (2013).

11. M. Z. Duz, K. S. Celik, I. Aydin, S. Erdogan, F. Aydin, and C. Hamamci, At. Spectrosc. 33, 78 (2012).

12. M. Merdivan, E. Yilmaz, C. Hamamci and R.S. Aygun, Food Chem. 87, 163 (2004).

13. M. Tuzen and M. Soylak, Food Chem. 102, 1089 (2007)

14. Y. Sahan, F. Basoglu and S.Gucer, Food Chem. 105, 395 (2007).

15. S. Erdogan, F. Yilmaz-Ersela, and M. Merdivan, Asian J. Chem. 18, 2159 (2006).

16. S. Tokalioglu and F. Gurbuz, Food Chem. 123, 183 (2010).

17. K.Y. Phan-Thien, G.C. Wright and N.A. Lee, Food Chem. 134, 453 (2012).

18. I. Aydin, F. Aydin, A. Saydut, E. G. Bakirdere and C. Hamamci, Microchem. J. 96, 247, (2010).

19. Elemental Contaminants in Dietary Supplements (<2232>), Pharmacopeial Forum 36(1) Jan/Feb 2010, update PF 37(3), May/June 2012.

20. A. K. Sharma and Ishwar Singh, Food Anal. Methods 2, 311 (2009).

21. F. Özkutlu, Y. Z. Dogru, N. Özenç, G. Yazici, M. Turan and F. Akçay, J Soil Sci. Environ. Managmt. 2, 25 (2011).

22. J. Naozuka, E. C. Vieira, A. N. Nascimento and P. V. Oliveira, Food Chem. 124, 1667 (2011)

23.Y.X. Xu, M.A. Hana and S.J. Josiah, Ind. Crop. Prod. 26, 69 (2007).

24. S. Keles and S.Bilgen, Renew. Sust. Energ. Rev. 16, 5199 (2012).

25 . I. Celikten, E. Mutlu and H. Solmaz, Renew. Energ. 48, 122 (2012).
26.A. Simsek, D. Korkmaz, Y. S. Velioglu and O. Y. Ataman, Food Chem. 83, 293 (2003).

27. A.Duran, M.Tuzen and M.Soylak, At. Spectrosc., 34, 99 (2013).

28. O. Akba, A. Baysal, M. Merdivan, C. Hamamci and B. Gumgum, Asian J. Chem. 17, 1518 (2005).

29. B. Gumgum and C. Hamamci, Spectrosc. Lett. 24, 1229 (1991).

30. F. Aydin, I. Aydin, S. Erdoğan, O. Akba, B. Isik and C. Hamamci, Pol. J. Environ. Stud. 21, 533 (2012).

31. I. Aydin, U. Yuksel, R. Guzel, B. Ziyadanogullari and F. Aydin, At. Spectrosc. 31, 67 (2010).

32. A. Yildiz, S. Erdogan, A. Saydut and C. Hamamci, Food Anal. Methods. 5, 591 (2012).

33. O. Akba, E. Kilinc, I. Aydin, S. Erdogan, F. Aydin, M.Z. Duz and C. Hamamci, At. Spectrosc. 32, 48 (2013).

34. F. C. Bressy, G. B. Brito, I. S. Barbosa, L.S.G. Teixeira and M. G. A. Korn, Microchem. J. 109, 145 (2013).

35. M.Yaman and H.I.Yaman, At. Spectrosc. 34, 191 (2013).

36. E. P. Nardi, F. S. Evangelista, L. Tormen, T. D. Saint Pierre, A. J. Curtius, S. S. de Souza and F. Barbosa, Jr., Food Chem. 112, 727 (2009).

37S. P. Dolan and S. G. Capar, J. Food Compos. Anal. 15, 593 (2002).

38. U. Cevik, N. Celik, A. Celik, N. Damla and K. Coskuncelebi, Food Chem. Toxicol. 47, 2351 (2009).

39. E P. Nardi, F. S. Evangelista, L. Tormen, T. D. Saint Pierre, A. J. Curtius, S. S. de Souza, and F. Barbosa Jr, Food Chem. 112, 727 (2009).

40. World Health Organization (WHO). In: Safety evaluation of certain food additives and contaminants. Sixty-first meeting of the Joint FAO/WHO Expert Committee on Food Additives (JECFA). WHO Food Additives Series, Geneva, Switzerland (2004). 